See discussions, stats, and author profiles for this publication at: https://www.researchgate.net/publication/273054127

\title{
Floridoside in the genus Laurencia (Rhodomelaceae: Ceramiales) - A chemosystematic study
}

Article in Phycologia · July 1995

DOI: 10.2216/i0031-8884-34-4-279.1

\section{CITATIONS}

19

4 authors, including:

Ulf Karsten

University of Rostock

389 PUBLICATIONS 11,142 CITATIONS

SEE PROFILE
READS

46

John A. West

University of Melbourne

289 PUBLICATIONS 6,610 CITATIONS

SEE PROFILE

Some of the authors of this publication are also working on these related projects:

Revision of the genera Sirodotia and Batrachospermum (Rhodophyta, Batrachospermales): sections Acarposporophytum, Aristata, Macrospora, Setacea, Turfosa and Virescentia View project

BIOACID View project 


\title{
Floridoside in the genus Laurencia (Rhodomelaceae: Ceramiales) - a chemosystematic study
}

\author{
K.D. BARROW ${ }^{1}$, U. KARSTEN ${ }^{2 *}$, R.J. KING ${ }^{3}$ AND J.A. WEST ${ }^{4}$ \\ ${ }^{1}$ School of Biochemistry and Molecular Genetics, University of New South Wales, Sydney NSW 2052, Australia \\ ${ }^{2}$ Max Planck Institute for Marine Microbiology, Fahrenheitstrasse 1, D-28359 Bremen, BRD \\ ${ }^{3}$ School of Biological Science, University of New South Wales, Sydney, NSW 2052, Australia \\ ${ }^{4}$ School of Botany, University of Melbourne, Parkville, VIC 3052, Australia
}

\begin{abstract}
K.D. BARROW, U. KARSTEN, R.J. KING AND R.J. WEST. 1995. Floridoside in the genus Laurencia (Rhodomelaceae: Ceramiales) - a chemosystematic study. Phycologia 34: 279-283.

The heteroside floridoside has been recorded in 21 specimens of Laurencia, as well as in some closely related species: Osmundea hybrida (A.P. de Candolle) Nam, O. pinnatifida (Hudson) Stackhouse, O. spectabilis (Postels et Ruprecht) Nam, $O$. truncata (Kützing) Nam et Maggs and Chondria capensis (Harvey) Askenasy (Rhodomelaceae, Ceramiales). The occurrence of this carbohydrate in the Ceramiales negates the proposition that the presence of floridoside is a chemotaxonomic marker only for orders of the Rhodophyta other than the Ceramiales. Digeneaside, which is known as a characteristic photo-assimilatory product only in representatives of the Ceramiales, was not detected in any of the species investigated, including five species in which it was previously detected; its previously proposed high diagnostic value is negated and its reported occurrence in these species is questioned.
\end{abstract}

\section{INTRODUCTION}

Members of all orders of Rhodophyta other than the Ceramiales synthesize the heteroside floridoside ( $\alpha$-D-galactopyranosyl-(1-2)-glycerol) and/or isofloridoside as a major product of photosynthesis and a storage compound. In the Ceramiales digeneaside ( $a$-D-mannopyranosy1-(1-2)-glycerate) is accumulated and has been regarded as a chemotaxonomic character (Kirst 1980; see also Kremer \& Vogl 1975; Kremer 1978a). Court (1980) investigated the photosynthetic properties of two algae in the order Ceramiales, Laurencia spectabilis Postels et Ruprecht and the alleloparasite Janczewkia gardneri Setchell et Guernsey, and found that the ${ }^{14} \mathrm{C}$ label was incorporated into a range of compounds including both floridoside and isofloridoside; no evidence was found for digeneaside, either labelled or unlabelled. Court's results directly contradicted the general conclusions of Kremer \& Vogl (1975) and Kremer (1978a, b). He provided limited data indicating that the discrepancy is unlikely to be due to seasonal or local environment differences, and suggested that a more discriminating and reliable study needed to be undertaken on the assimilation products of Laurencia and related genera. Very recently some Laurencia species including $L$. spectabilis have been transferred to the resurrected genus Osmundea (Nam et al. 1994). These authors recognized Osmundea as different from Laurencia, due to anatomical characters of vegetative and male reproductive structures and tetrasporangial development.

In a routine ${ }^{13} \mathrm{C}$-nuclear magnetic resonance spectroscopy $\left({ }^{13} \mathrm{C}-\mathrm{NMR}\right)$ investigation of potential osmoregulatory compounds in a range of red algae, we noted the consistent presence of floridoside in different isolates of Laurencia fili-

* Author for correspondence. formis (C. Agardh) Montagne and therefore undertook a survey of members of this genus and several closely related species, which clarifies the issue raised by Court (1980).

\section{MATERIALS AND METHODS}

\section{Plant material}

All details of the collection locations and dates of the algae used for chemical analysis are presented in Table 1. Most species were collected in the field at low tide and subsequently air-dried in the sun prior to chemical analysis. Other samples were collected by colleagues around the world and mailed as dried material. In addition, some herbarium specimens were included in the study.

\section{${ }^{13}$ C-NMR methodology}

For the ${ }^{13} \mathrm{C}-\mathrm{NMR}$ measurements usually $100-500 \mathrm{mg}$ of algal dry weight (DW) was extracted in $5 \mathrm{ml} 70 \%$ ethanol (v/v) for $3 \mathrm{~h}$ in a waterbath at $70^{\circ} \mathrm{C}$. After centrifugation at $5000 \mathrm{~g}$, the supernatant was evaporated to dryness and redissolved in $0.5 \mathrm{ml} \mathrm{D}_{2} \mathrm{O}(99.98 \%)$ for NMR spectroscopy. For some samples the extraction was repeated three times to check the efficiency of the procedure. Occasionally there was so much water-insoluble material present in the evaporated extracts that it was necessary to carry out a preliminary trituration with ether to obtain a sample suitable for NMR. In one case (Laurencia filiformis) a large-scale extraction was carried out with $1 \mathrm{~kg}$ of algal fresh weight. The procedure was essentially the same except that, after evaporation, the residue of the alcoholic extract was partitioned between dichloromethane and water, and the aqueous phase then evaporated. ${ }^{13} \mathrm{C}-\mathrm{NMR}$ 
Table 1. The floridoside concentration in field and herbarium species of Laurencia and Osmundea from different geographic regions and in Chondria capensis from South Africa. Data are expressed as mean \pm standard deviation $(\mathrm{n}=4)$ in $\mathrm{mmol} \mathrm{kg}^{-1} \mathrm{DW}$. Some samples could only be used for one chemical analysis, due to small amounts of material

\begin{tabular}{|c|c|c|c|c|}
\hline Species & Location & Date & Collector & Floridoside \\
\hline Laurencia arbuscula Sonder & $\begin{array}{l}\text { Williamstown, Victoria, } \\
\text { Australia }\end{array}$ & 5 Aug. 93 & J.A. West & $163.0 \pm 32.0$ \\
\hline L. arbuscula & $\begin{array}{l}\text { Williamstown, Victoria, } \\
\text { Australia }\end{array}$ & 5 Aug. 93 & J.A. West & $120.6 \pm 19.1$ \\
\hline L. botryoides (Turner) Gaillon & Eaglehawk, Tasmania & Nov. 1924 & $\begin{array}{l}\text { Herbarium Botanical Garden } \\
\text { Sydney }\end{array}$ & 26.1 \\
\hline L. brongniartii J. Agardh & Coloundra, Australia & Aug. 1922 & $\begin{array}{l}\text { Herbarium Botanical Garden } \\
\text { Sydney }\end{array}$ & 44.1 \\
\hline $\begin{array}{l}\text { L. filiformis (C. Agardh) } \\
\text { Montagne }\end{array}$ & Maroubra, Sydney, Australia, & 5 Nov. 92 & U. Karsten & $289.0 \pm 24.5$ \\
\hline L. filiformis & Maroubra, Sydney, Australia & 24 Nov. 92 & U. Karsten & $335.5 \pm 55.8$ \\
\hline L. filiformis & La Perouse, Sydney, Australia & 13 Oct. 92 & R. DeNys & $159.5 \pm 4.1$ \\
\hline L. filiformis & $\begin{array}{l}\text { Williamstown, Victoria, } \\
\text { Australia, }\end{array}$ & 5 Aug. 93 & J.A. West & $109.6 \pm 9.0$ \\
\hline $\begin{array}{l}\text { L. fliformis forma heteroclada } \\
\text { (Harvey) Saito et Womersley }\end{array}$ & $\begin{array}{l}\text { Twelve Apostles, Victoria, } \\
\text { Australia, }\end{array}$ & 19 Jan. 93 & U. Karsten & $1303.5 \pm 232.3$ \\
\hline L. filiformis forma heteroclada & Robe, South Australia & 20 Jan. 93 & U. Karsten & 114.7 \\
\hline L. flagellifera J. Agardh & Brava Beach, Sao Paulo, Brazil & 15 Sep. 93 & M. Fujii & $20.7 \pm 13.1$ \\
\hline L. furcata sp. nov. Fujii & Capula, Espiritu Santo, Brazil & 30 Jun. 92 & M. Fujii & 25.3 \\
\hline L. inplicata J. Agardh & $\begin{array}{l}\text { Geoffrey Bay, Magnetic Island, } \\
\text { Australia }\end{array}$ & 26 Sep. 92 & I. Price & $417.5 \pm 69.7$ \\
\hline L. majuscula (Harvey) Lucas & $\begin{array}{l}\text { Williamstown, Victoria, } \\
\text { Australia }\end{array}$ & 5 Aug. 93 & J.A. West & $146.0 \pm 3.1$ \\
\hline L. obtusa (Hudson) Lamouroux & Dumaguete City, the Philippines & 10 Jun. 93 & N. Calumpong & $5.3 \pm 2.9$ \\
\hline L. obtusa & Doorin Point, Donegal, Ireland & 15 Oct. 89 & C. Maggs & $46.0 \pm 24.0$ \\
\hline L. obtusa & $\begin{array}{l}\text { Hainan, Peoples Republic of } \\
\text { China }\end{array}$ & Feb. 92 & B. Bischoff & $78.7^{-}$ \\
\hline $\begin{array}{l}\text { L. osmunda (S.G. Gmelin) } \\
\text { Maggs et Hommersand }\end{array}$ & Torbay, Devon, England & 10 Mar. 89 & C. Maggs & $60.3 \pm 51.3$ \\
\hline L. pacifica Kylin & Stillwater Cove, California, USA & 5 May 74 & J.A. West & $40.3 \pm 10.2$ \\
\hline L. pacifica & Stillwater Cove, California, USA & 9 May 93 & J.A. West & $206.1 \pm 20.7$ \\
\hline L. papillosa (C. Agardh) Greville & Dumaguete City, the Philippines & 10 Jun. 93 & N. Calumpong & $<0.5$ \\
\hline $\begin{array}{l}\text { L. patentiramea (Montagne) } \\
\text { Kützing }\end{array}$ & Dumaguete City, the Philippines & 10 Jun. 93 & N. Calumpong & $<0.5$ \\
\hline L. poiteaui (Lamouroux) Howe & La Parguera, Puerto Rico & 2 Jun. 93 & D. Ballantine & $125.8 \pm 9.2$ \\
\hline L. pyramidalis Bory ex Kützing & $\begin{array}{l}\text { West Point, Isles of Scilly, } \\
\text { England }\end{array}$ & 26 Sep. 88 & C. Maggs & $35.4 \pm 26.0$ \\
\hline L. scoparia J. Agardh & Brava Beach, Sao Paulo, Brazil & 15 Sep. 93 & M. Fujii & $30.5 \pm 28.5$ \\
\hline L. similis Nam et Saito & $\begin{array}{l}\text { Geoffrey Bay, Magnetic Island, } \\
\text { Australia }\end{array}$ & 26 Sep. 92 & I. Price & $228.7 \pm 34.9$ \\
\hline $\begin{array}{l}\text { L. subopposita (J. Agardh) } \\
\text { Setchell }\end{array}$ & $\begin{array}{l}\text { Stillwater Cove, California, } \\
\text { USA, }\end{array}$ & 9 May 93 & J.A. West & $386.6 \pm 34.2$ \\
\hline L. tenera Tseng & $\begin{array}{l}\text { Kissing Point, Townsville, } \\
\text { Australia }\end{array}$ & 27 Aug. 92 & I. Price & $386.2 \pm 56.1$ \\
\hline L. tumida Saito et Womersley & $\begin{array}{l}\text { Williamstown, Victoria, } \\
\text { Australia }\end{array}$ & 5 Aug. 93 & J.A. West & $60.6 \pm 17.4$ \\
\hline L. $s p$. & Robe, South Australia & 20 Jan. 93 & U. Karsten & 120.0 \\
\hline L. $s p$. & Ishigaki, Japan & 10 Sep. 93 & E. Coppejans (Herbarium EC 9989) & $207.1 \pm 42.4$ \\
\hline $\begin{array}{l}\text { Osmundea hybrida (A.P. de } \\
\text { Candolle) Nam }\end{array}$ & Ballycastle, Northern Ireland & 7 Feb. 89 & C. Maggs & $154.5 \pm 48.0$ \\
\hline $\begin{array}{l}\text { O. pinnatifida (Hudson) } \\
\text { Stackhouse }\end{array}$ & $\begin{array}{l}\text { Island Magee, Antrim, Northern } \\
\text { Ireland }\end{array}$ & $20 \mathrm{Feb} .89$ & C. Maggs & $140.2 \pm 40.4$ \\
\hline $\begin{array}{l}\text { O. spectabilis (Postels et } \\
\text { Ruprecht) Nam }\end{array}$ & Duxbury Reed, California, USA & 10 Dec. 77 & Herbarium University of California & $252.8 \pm 51.3$ \\
\hline O. spectabilis & $\begin{array}{l}\text { Goverment Point, California, } \\
\text { USA }\end{array}$ & 27 Dec. 47 & Herbarium University of California & $35.1 \pm 33.2$ \\
\hline O. spectabilis & Pidgeon Point, California, USA & 9 Apr. 93 & J.A. West & $226.7 \pm 35.2$ \\
\hline O. spectabilis & Agate Beach, California, USA & 7 May 93 & J.A. West & $138.4 \pm 18.6$ \\
\hline O. spectabilis & Stillwater Cove, California, USA & 9 May 93 & J.A. West & $523.3 \pm 60.1$ \\
\hline $\begin{array}{l}\text { O. truncata (Kützing) Nam et } \\
\text { Maggs }\end{array}$ & Lyme Regis, Dorset, England & 26 Apr. 90 & C. Maggs & $302.2 \pm 19.7$ \\
\hline $\begin{array}{l}\text { Chondria capensis (Harvey) } \\
\text { Askenasy }\end{array}$ & Cape Province, South Africa & $6 \mathrm{Jul} .93$ & R.J. King & $56.2 \pm 43.7$ \\
\hline
\end{tabular}

spectra were recorded on a Bruker AM-500 spectrometer at 125.77 MHz. Typically a sweep width of $30000 \mathrm{~Hz}, 16000$ time domain points and a $60^{\circ}$ pulse of $3.5 \mu \mathrm{s}$ were used for acquisition, with composite pulse decoupling. The free induction decay was zero-filled to 32000 data points and processed with a line broadening of $1.5 \mathrm{~Hz}$. Samples were contained in 
spinning $5 \mathrm{~mm}$ tubes and spectra were run at $27^{\circ} \mathrm{C}$ and referenced from added dioxane $(67.4 \mathrm{ppm})$.

\section{Floridoside quantification}

Floridoside was quantified by gas-liquid chromatography (GLC) and high-pressure liquid chromatography (HPLC). For both measurements the algal samples (10-15 mg DW) were extracted in $1 \mathrm{ml} \mathrm{70 \%} \mathrm{ethanol} \mathrm{(v/v)} \mathrm{for} \mathrm{about} 3 \mathrm{~h}$ in a waterbath at $70^{\circ} \mathrm{C}$. These were then centrifuged for $5 \mathrm{~min}$ at $5000 \mathrm{~g}$.

For the GLC analysis, $10 \mu \mathrm{l}$ of the internal standard myoinositol $\left(1 \mathrm{mg} \mathrm{ml}^{-1}\right)$ was added to $30-100 \mu \mathrm{l}$ of the sample supernatant or to a standard of known concentration, and evaporated to dryness under a stream of dry air. The residue was re-dissolved in $150 \mu \mathrm{l}$ pyridine and $20 \mu \mathrm{l}$ of the silylation reagent $\mathrm{N}$-trimethylsilylimidazole (TMSI) (Pierce Chemical Co., Rockford, USA), shaken for $30 \mathrm{~s}$ and left overnight. The silylated samples were analysed directly by GLC. The determinations were performed with a Hewlett-Packard 5890A GLC equipped with a flame-ionization detector and connected to an automatic injector 7633. Data were analysed and processed using a Hewlett-Packard GC ChemStation. A fused-silica capillary column (BP5, $25 \mathrm{~m} \times 0.32 \mathrm{~mm}$ ID) was used, with hydrogen as the carrier gas at a head pressure of $10 \mathrm{psi}$. Floridoside was separated from other carbohydrates with a temperature program: the oven temperature was kept for $1 \mathrm{~min}$ at $150^{\circ} \mathrm{C}$ following injection $(1 \mu \mathrm{l})$ and then raised at $40^{\circ} \mathrm{C} \mathrm{min}^{-1}$ to $260^{\circ} \mathrm{C}$, where it was left for $2 \mathrm{~min}$. The injection port and the detector were heated to $300^{\circ} \mathrm{C}$.

For the HPLC measurements, $700 \mu 1$ of the supernatant was evaporated to dryness under vacuum (Speed Vac Concentrator SVC 100H, Bachofer Ltd, BRD). Dried samples were redissolved in $700 \mu \mathrm{l}$ distilled water, purified through a $0.45-\mu \mathrm{m}$ syringe microfilter and directly utilized for analysis. Floridoside was quantified by HPLC with a refractive index detector. All analytical conditions are described in detail by Karsten et al. (1991).

Calibration of both chromatography systems was made using a pure floridoside standard isolated from the red alga Delisea pulchra (Greville) Montagne, collected at Cape Banks, Botany Bay, Sydney. The standard was prepared as reported by Karsten et al. (1993a). The floridoside contents are expressed as concentration on a dry-weight basis.

\section{RESULTS}

Except for the herbarium specimens of Laurencia, all other plants listed in Table 1 were investigated by ${ }^{13} \mathrm{C}-\mathrm{NMR}$ spectroscopy. The spectra of all samples showed nine major resonances at $61.3,61.9,62.3,69.3,70.1,70.2,71.9,79.6$ and $98.9 \mathrm{ppm}$, which are characteristic for floridoside (Karsten et al. 1993b). Digeneaside, which gives typical resonances at $61.8,63.9,67.6,70.9,71.2,73.8,78.8,99.3$ and $177.7 \mathrm{ppm}$ (Karsten et al. 1994) could not be detected in any of the samples tested. The quantitative data for floridoside in all species of Laurencia and Osmundea, as well as in Chondria capensis, are provided in Table 1. Floridoside was detected in all algae examined, but there was considerable variation even within single species. The concentrations ranged from trace amounts of $<0.5 \mathrm{mmol} \mathrm{kg}{ }^{-1} \mathrm{DW}$ (e.g. L. papillosa
(C. Agardh) Greville) up to $1303.5 \mathrm{mmol} \mathrm{kg}{ }^{-1} \mathrm{DW}$ in $L$. filiformis forma heteroclada (Harvey) Saito et Womersley (Table 1). Usually we recorded $800-1000$ scans on each sample and typically the signal to noise ratio for the floridoside resonances was 5-10 to 1 . Under these conditions it would not be possible to detect digeneaside at amounts of $0.5 \%$ or less of floridoside. Therefore selected samples were run for much longer times and signal to noise ratios of 50-100 to 1 were obtained. Using a larger line broadening factor also increased the signal to noise ratio and hence the sensitivity of detection. This was performed for samples of $L$. filiformis, $L$. majuscula (Harvey) Lucas and L. tumida Saito et Womersley, and the results indicate that if digeneaside is present in these species it must be at concentrations of less than $0.5 \%$ of that of floridoside. To check further, a largescale extraction of $L$. filiformis was carried out and part of this extract run at a much higher concentration. Again no digeneaside could be detected and, if any is present, it must be at concentrations less than $0.05-0.1 \%$ of floridoside. Many of the extracts showed other resonances with peaks in the range between 25 and $55 \mathrm{ppm}$ and these were very speciesspecific. Preliminary ion exchange chromatography has shown that these compounds are retained on sulphonic acid ion exchange resins and so must have certain basic structural groups. In some cases these resonances were considerably larger than those for floridoside and these compounds may contribute significantly to osmotic adjustment. We also checked very carefully for the presence of any of the isofloridoside isomers. None were detected in any samples examined in this work.

\section{DISCUSSION}

The use of the presence or absence of various chemical constituents in algal taxonomy has a long history: by the middle of the nineteenth century W.H. Harvey was already using a classification of the major groups of algae based largely on colour. Subsequent studies have established the complement of pigments diagnostic of the different algal divisions as well as the major reserve substances and the organic cell-wall components (Percival 1979; Kremer 1980; Rowan 1989).

Within the red algae, the diversity of photosynthetic products, some of which are known to function as compatible solutes in osmoregulation (Kirst 1990), have been considered to be of taxonomic use for this group (Kremer 1978a, 1980). In all orders other than the Ceramiales the main compounds reported are the heterosides, floridoside and/or isofloridoside. In the Ceramiales, digeneaside is usually present and has been thought to be of high chemosystematic value (Kirst 1980; Kremer \& Kirst 1982). Kremer \& Vogl (1975) and Kremer (1978) detected digeneaside in Osmundea hybrida (as Laurencia hybrida), O. pinnatifida (as Laurencia pinnatifida), Laurencia obtusa (Hudson) Lamouroux and L. subopposita (J. Agardh) Setchell after ${ }^{14} \mathrm{C}$-labelling followed by thin-layer chromatography and autoradiography. Kirst (1980) measured digeneaside in $L$. obtusa using an enzymatic test which is based on an acid hydrolysis and the subsequent oxidation of free glyceric acid to hydroxy pyruvic acid by $\mathrm{NAD}^{+}$and glyceric acid dehydrogenase. We included these Laurencia and Osmun- 
dea species in our study and were unable to find detectable traces of digeneaside by using the powerful and accurate ${ }^{13} \mathrm{C}$ NMR technique. Instead, floridoside was present in all samples tested. It seems possible that the earlier data were due to methodological inaccuracies. The occurrence of floridoside also in Osmundea and Chondria capensis, i.e. in further genera of the Ceramiales, points to the possibility that more representatives of the order may contain this heteroside, therefore the proposed high diagnostic value of digeneaside for the Ceramiales has to be revised. Besides the occurrence of floridoside in Laurencia, other biochemical exceptions are known within the Ceramiales. The members of the Bostrychioideae (Rhodomelaceae, Ceramiales), for example, are characterized by the sugar alcohols dulcitol and sorbitol, which are otherwise very unusual in red algae (Karsten et al. 1992a). Both polyols are strongly involved in osmotic acclimation (Karsten et al. 1993b). In most Bostrychia species both compounds occur; but in the related genus Stictosiphonia, dulcitol is lacking (Karsten et al. 1992a). Recently, we have shown that in Caloglossa (Delesseriaceae, Ceramiales) the main low molecular weight carbohydrate is mannitol, which also appears to function in osmoregulation (Karsten et al. 1992b). Among the macroalgae, the presence of mannitol had been regarded as an important chemotaxonomic marker for the brown algae, despite earlier reports of mannitol in the red alga Neorhodomela larix (Turner) Masuda (as Rhodomela larix (Turner) C. Agardh) (Whyte \& Southcott 1970). In Ceramium flaccidum (Kützing) Ardissone (Ceramiaceae, Ceramiales), isethionic acid (2-hydroxyethane sulphonic acid) has been isolated and purified (Barrow et al. 1993). In that species it occurred in higher concentrations than does digeneaside; but, to our knowledge, no obvious biological function in algae has been ascribed to it. The detection of mannitol in Caloglossa and of isethionic acid in Ceramium emphasizes the importance of the use of sophisticated analytical methods ( ${ }^{13} \mathrm{C}-\mathrm{NMR}$ along with GLC and/or HPLC). Such techniques allow for rapid and accurate screening for a range of low molecular-weight carbohydrates, betaines and similar compounds (Blunden et al. 1992). The results from these studies cited and the present one also stress the need for broad and representative sampling with taxa before generalizations can be made. Since these compounds can have a physiological role other than simply carbon and/or nitrogen storage, it may be that ecological conditions rather than phylogenetic relations are the factor(s) determining their presence. The genera Caloglossa, Bostrychia and Stictosiphonia with sugar alcohols are all characteristic for the upper littoral zone in saltmarsh and mangrove habitats and the occurrence of high concentrations of unusual compounds may indicate biochemical adaptations to that specific environment. There may also be seasonal changes in the quantitative aspects of storage products. For example, in Bangia atropurpurea (Roth) C. Agardh and Porphyra columbina Montagne, floridoside and both $\mathrm{D}$ - and L-isofloridoside have been recorded; but, there were significant changes in the relative and absolute amounts throughout the season and at times particular heterosides could not necessarily be detected (Karsten et al. 1993b). In both species the lowest heteroside concentrations were determined in winter, whereas in summer the values peaked. A similar seasonal effect was observed in our study for floridoside in Laurencia filiformis. In the Australian winter
(August) plants of this species exhibited a floridoside content of $109.6 \mathrm{mmol} \mathrm{kg}^{-1} \mathrm{DW}$. Between October and November, the concentrations increased from 159.5 to $335.5 \mathrm{mmol} \mathrm{kg}$ DW (Table 1). Besides these results, however, the present study demonstrates considerable variation within Laurencia species and there are insufficient data to draw any general conclusions.

The data presented fit in with the observations of Court (1980) that floridoside is a major compound in the genus Laurencia and are directly in opposition to the generalization that its absence be considered typical of the order Ceramiales.

\section{ACKNOWLEDGEMENTS}

UK was supported by the Deutsche Forschungsgemeinschaft, the Max Planck Gesellschaft and by a travel grant from the Joyce W. Vickery Scientific Research Fund of the Linnean Society of New South Wales. We deeply thank David Ballantine, Bettina Bischoff, Nida Calumpong, Eric Coppejans, Rocky DeNys, Mutue Fujii, Christine Maggs, Alan Millar, Ian Price and Paul Silva for sending Laurencia samples. We are grateful to Brian Womersley for the determination of the Australian species of Laurencia. The authors also wish to thank Claudia Daniel, Irene Dunker and Sabine Koch for technical help.

\section{REFERENCES}

BARROW K.D., KARSTEN U. \& KING R.J. 1993. Isethionic acid from the marine red alga Ceramium flaccidum. Phytochemistry 34: 1429-1430.

Blunden G., Smith B.E., Irons M.W., Yang M.H., Roch O.G. \& PATEL A.V. 1992. Betaines and tertiary sulphonium compounds from 62 species of marine algae. Biochemical Systematics and Ecology 20: 373-388.

COURT G.J. 1980. Photosynthesis and translocation studies of Laurencia spectabilis and its symbiont Janczewskia gardneri (Rhodophyceae). Journal of Phycology 16: 270-279.

Karsten U., Thomas D.N., Weykam G., Daniel C. \& Kirst G.O 1991. A simple and rapid method for extraction and separation of low molecular weight carbohydrates from marine macroalgae using high performance liquid chromatography. Plant Physiology and Biochemistry 29: 373-378.

Karsten U., West J.A. \& Zuccarello G. 1992a. Polyol content of Bostrychia and Stictosiphonia (Rhodomelaceae, Rhodophyta) from field and culture. Botanica Marina 35: 11-19.

Karsten U., West J.A., Mostaert A.S., KIng R.J., Barrow K.D. \& KirST G.O. 1992b. Mannitol in the red algal genus Caloglossa. Journal of Plant Physiology 140: 292-297.

KARSTEN U., West J.A. \& GANESAN E.K. 1993a. Comparative physiological ecology of Bostrychia moritziana (Ceramiales, Rhodophyta) from freshwater and marine habitats. Phycologia 32: 401-409.

Karsten U., Barrow K.D. \& KIng R.J. 1993b. Floridoside, $\mathrm{L}$-isofloridoside and D-isofloridoside in the red alga Porphyra columbina. Plant Physiology 103: 485-491.

Karsten U., Barrow K.D., Mostaert A.S., King R.J. \& West J.A. 1994. ${ }^{13} \mathrm{C}$ - and ${ }^{1} \mathrm{H}-\mathrm{NMR}$ studies on digeneaside in the red alga Caloglossa leprieurii - a re-evaluation of its osmotic significance. Plant Physiology and Biochemistry 32: 669-676.

KIRST G.O. 1980. Low mw carbohydrate and ions in Rhodophyceae: quantitative measurement of floridoside and digeneaside. Phytochemistry 19: 1107-1110.

KIRST G.O. 1990. Salinity tolerance of eukaryotic marine algae. 
Annual Review in Plant Physiology and Plant Molecular Biology 41: 21-53.

KREMER B.P. \& KIRST G.O. 1981. Biosynthesis of 2-O-D-glycerolD-galactopyranoside (floridoside) in marine Rhodophyceae. Plant Science Letters 23: 349-357.

KREMER B.P. \& VOGL R. 1975. Zur chemotaxonomischen Bedeutung des $\left[{ }^{14} \mathrm{C}\right]-$ Markierungsmusters bei Rhodophyceen. Phytochemistry 14: 1309-1314.

KREMER B.P. 1978a. Patterns of photoassimilatory products in Pacific Rhodophyceae. Canadian Journal of Botany 56: 1655-1659.

KREMER B.P. 1978b. Studies in ${ }^{14} \mathrm{CO}_{2}$-assimilation in marine Rhodophyceae. Marine Biology 48: 47-54.

KREMER B.P. 1980. Taxonomic implications of algal photoassimilate patterns. British Phycological Journal 15: 399-409.
Nam K.W., Maggs C.A. \& Garbary D.J. 1994. Resurrection of the genus Osmundea with an emendation of the generic delineation of Laurencia (Ceramiales, Rhodophyta). Phycologia 33: 384-395.

Percival E. 1979. The polysaccharides of green, red and brown seaweeds: their basic structure, biosynthesis and function. British Phycological Journal 14: 103-117.

Rowan K.S. 1989. Photosynthetic Pigments of Algae. Cambridge University Press, London. 334 pp.

Whyte J.N.C. \& SouthCotT B.A. 1970. An extraction procedure for plants: extracts from the red alga Rhodomela larix. Phytochemistry 9: 1159-1161.

Accepted 21 December 1994 